\title{
Electronic Excitations of the Green Fluorescent Protein Chromophore in Its Protonation States: SAC/SAC-CI Study
}

\author{
ABHIJIT K. DAS, * JUN-YA HASEGAWA, TOMOO MIYAHARA, MASAHIRO EHARA, \\ HIROSHI NAKATSUJI \\ Department of Synthetic Chemistry and Biological Chemistry, Graduate School of Engineering, \\ Kyoto University, Kyoto 606-8501, Japan
}

Received 23 December 2002; Accepted 31 March 2003

\begin{abstract}
Two ground-state protonation forms causing different absorption peaks of the green fluorescent protein chromophore were investigated by the quantum mechanical SAC/SAC-CI method with regard to the excitation energy, fluorescence energy, and ground-state stability. The environmental effect was taken into account by a continuum spherical cavity model. The first excited state, HOMO-LUMO excitation, has the largest transition moment and thus is thought to be the source of the absorption. The neutral and anionic forms were assigned to the protonation states for the experimental A- and B-forms, respectively. The present results support the previous experimental observations.
\end{abstract}

(C) 2003 Wiley Periodicals, Inc. J Comput Chem 24: 1421-1431, 2003

Key words: green fluorescent protein chromophore; SAC-CI method; excited states; fluorescence; protonation state in the ground state

\section{Introduction}

Since the discovery of green fluorescent protein (GFP) ${ }^{1-4}$ many studies have examined its photo-physical and -chemical properties, not only to better understand the unusual optical spectroscopic characteristics of the GFP chromophore (GFPC), but also to find a wide range of applications in molecular genetics, biochemistry, and cell biology (see refs. 5-8 for reviews). The GFP of the jellyfish Aequorea victoria is made up of 238 amino-acid residues ${ }^{9}$ and produces a greenish fluorescence $\left(\lambda_{\max }=508 \mathrm{~nm}\right) .{ }^{9,10}$ The absorption spectrum of wildtype GFP consists of two broad peaks at $478(2.60 \mathrm{eV})$ and 398 $\mathrm{nm}(3.13 \mathrm{eV}) .{ }^{11-14}$ Because the ratio of the two peaks depends on the $\mathrm{pH}$, temperature, and ionic strength, ${ }^{15}$ the two peaks at 398 and $478 \mathrm{~nm}$ can be ascribed to two different ground states, A- and B-forms, respectively, which differ with regard to their protonation state. ${ }^{13,15}$ Emission from the $\mathrm{A}^{*}$ - and $\mathrm{B}^{*}$-forms is observed, respectively, at $420-470 \mathrm{~nm}(2.64-2.95 \mathrm{eV})$ and 482 $\mathrm{nm}(2.57 \mathrm{eV}) .{ }^{13,14}$ Further, a study of its excited-state dynamics ${ }^{13,14}$ proposed that the structure could be converted to an intermediate I-form that emits at $508 \mathrm{~nm}(2.44 \mathrm{eV})$.

There have been many studies on the denatured GFPC ${ }^{15,16}$ and a model compound. ${ }^{17-22}$ The first $(398 \mathrm{~nm})$ and second $(478 \mathrm{~nm})$ peaks were assigned to the neutral (A-form) and anionic forms (B-form), respectively. ${ }^{17,19}$ A Raman spectroscopic study ${ }^{17}$ with a model compound in solution showed that the chromophore has two macroscopic $\mathrm{p} K_{\mathrm{a}}$ values of 1.8 and 8.2, which are attributed to ionization of the imidazolinone-ring nitrogen and the phenolic hydroxyl group, respectively. Semiempirical quantum mechanical calculations gave the same assignment. ${ }^{19}$ The other protonation state, I-form, has been shown by hole-burning spectroscopy to contribute to the absorption spectrum of wild-type GFP as a broad wing to the red-side of the $475 \mathrm{~nm}$ peak. ${ }^{14}$ Quantum mechanical calculations using semiempirical methods predicted a zwitterionic ground state. ${ }^{19}$ Recently, experimental absorption spectra have been reported for the anionic and cationic GFP model compounds in vacuo. ${ }^{23,24}$ The observed peak positions for the anion form are very close to those observed for the wild-type. This result indicates that the protein environment effectively shields the chromophore from the solvation. ${ }^{23}$ These results are also useful for evaluating the theoretical calculations.

The environmental effect due to protein residues is not necessarily equivalent to that in solution. The local $\mathrm{pH}$ caused by proximate residues is not likely identical among the three proto-

Correspondence to: H. Nakatsuji; e-mail: hiroshi@sbchem.kyoto-u.ac.jp

*Permanent address: Department of Spectroscopy, Indian Association for the Cultivation of Science, Jadavpur, Kolkata 700 032, India

Contract/grant sponsor: Ministry of Education, Culture, Sports, Science, and Technology of Japan

Contract/grant sponsor: Matsuo Foundation 
nation sites in the chromophore, as clearly seen in X-ray structures. $^{25-27}$ In a previous study using a hybrid B3LYP density functional theory (DFT), the $\mathrm{p} K_{\mathrm{a}}$ values and free energies for all possible forms of the chromophore were derived, and six possible forms of the denatured GFPC, instead of just the two widely assumed forms, neutral and anionic, were suggested. ${ }^{28}$ The results indicated that at $\mathrm{pH}$ within the range of 1.1 to 9.4, neutral, zwitterionic, and anionic forms can exist. ${ }^{28}$ Therefore, a calculation of the excitation energy for the different forms of the chromophores could be expected to give important information about the protonation state. The absorption peak position was studied for eight forms of the chromophore by the semiempirical NDDO-G method. ${ }^{19}$ The results were in reasonable agreement with the experimental absorption spectra, although the method used is less reliable than the modern quantitative methodology. Fluorescence was not investigated in that study. MCSCF/MCQDPT calculations $^{29}$ were also carried out for the vertical and adiabatic excitation energies and for fluorescence energies. However, the results for the neutral and anionic chromophore were different from the experimental values, likely due to the small active space used. Therefore, reliable calculations of the excitation and fluorescence energies for various protonation states would be very useful for determining the ground-state structure of the chromophore in intact wild-type GFP, which could be an important starting point for further studies of the interesting photochemistry of the GFP protein. ${ }^{19,30-32}$

In this article, we used the $\mathrm{SAC}^{33} / \mathrm{SAC}-\mathrm{CI}^{34-36}$ method $^{37,38}$ to study the low- and high-lying electronic excitations of a GFP model chromophore in its various protonation states in the gas phase and in solution. Using the optimized geometry for the excited state, the fluorescence energy was computed. The polarization effect of protein was taken into account by a continuum model. ${ }^{39,40}$ The SAC/SAC-CI method has been successfully used in various spectroscopic studies ${ }^{29}$ of molecules ranging in size from water ${ }^{41}$ to porphyrin dimers, ${ }^{42}$ and is widely accepted as a reliable tool for studying the excited states of atoms and molecules. In this article, we used the SAC-CI SD- $R$ method, in which the SAC-CI-linked $R$ operators consist of singles and doubles, because the excitations are essentially described by one-electron processes. ${ }^{19,29,30}$ The next section provides details of the calculations. In the third section, we explain the results for the ground-state energy, excitation energy, and fluorescence energy for various protonation states. The possible assignment of the ground-state protonation is also discussed at the end of the section.

\section{Method}

The GFPC $\mathrm{C}_{11} \mathrm{H}_{10} \mathrm{~N}_{2} \mathrm{O}_{2}$ is assumed to have $\mathrm{C}_{\mathrm{s}}$ symmetry, because the optimized geometry for various protonation states turned out to be more or less planar in a previous study. ${ }^{28}$ The neutral state of the chromophore is shown in Figure 1. The atomic coordinates are taken from the crystallographic data of Kurimoto et al. ${ }^{43}$ The chromophore consists of 106 electrons and 25 atoms. The chromophore has three protonation sites: the phenolic oxygen $\mathrm{O}_{\mathrm{Y}}$, the carbonyl oxygen $\mathrm{O}_{\mathrm{X}}$, and the imidazolinone nitrogen $\mathrm{N}$ indicated in the figure. The protonation of the chromophore is represented as $\left(X \mathrm{O}_{\mathrm{Y}}, X \mathrm{~N}, X \mathrm{O}_{\mathrm{X}}\right)^{Y}$, where $X=\mathrm{H}$ if the position is protonated and

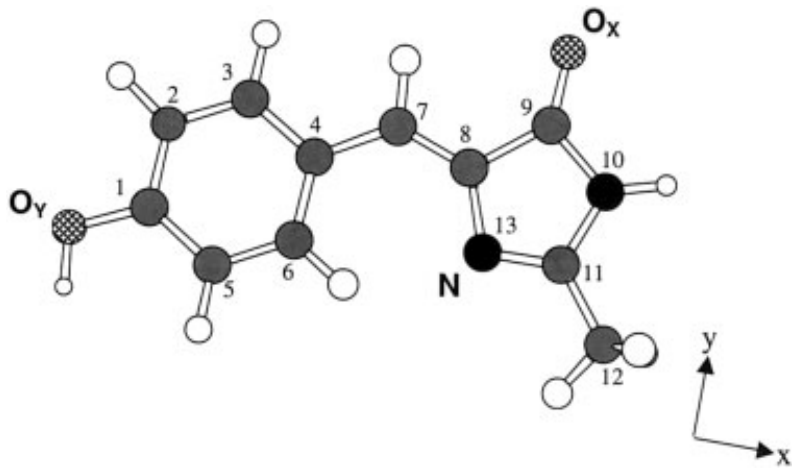

Figure 1. Structure of the green fluorescent protein (GFP) chromophore model in the neutral form. The three protonation sites are marked $\mathrm{O}_{\mathrm{Y}}, \mathrm{N}$, and $\mathrm{O}_{\mathrm{X}}$. The protonation state of the chromophore is indicated as $\left(X \mathrm{O}_{\mathrm{Y}}, X \mathrm{~N}, X \mathrm{O}_{\mathrm{X}}\right)$, where $X=\mathrm{H}$ if protonated. For example, the neutral form shown is $\left(\mathrm{HO}_{\mathrm{Y}}, \mathrm{N}, \mathrm{O}_{X}\right)$.

$Y$ is the charge of the system. We considered the following structures: the neutral form $\left(\mathrm{HO}_{\mathrm{Y}}, \mathrm{N}, \mathrm{O}_{\mathrm{X}}\right)$ (shown in Fig. 1), the cationic forms $\left(\mathrm{HO}_{\mathrm{Y}}, \mathrm{HN}^{+}, \mathrm{O}_{\mathrm{X}}\right)^{+},\left(\mathrm{O}_{\mathrm{Y}}^{-}, \mathrm{HN}^{+}, \mathrm{HO}_{\mathrm{X}}^{+}\right)^{+}$, and $\left(\mathrm{HO}_{\mathrm{Y}}, \mathrm{N}, \mathrm{HO}_{\mathrm{X}}^{+}\right)^{+}$, the dicationic form $\left(\mathrm{HO}_{\mathrm{Y}}, \mathrm{HN}^{+}, \mathrm{HO}_{\mathrm{X}}^{+}\right)^{2+}$, the deprotonated anionic form $\left(\mathrm{O}_{\mathrm{Y}}^{-}, \mathrm{N}, \mathrm{O}_{\mathrm{X}}\right)^{-}$, and the zwitterionic forms $\left(\mathrm{O}_{\mathrm{Y}}^{-} \mathrm{NH}^{+}, \mathrm{O}_{\mathrm{X}}\right)$ and $\left(\mathrm{O}_{\mathrm{Y}}^{-}, \mathrm{N}, \mathrm{HO}_{\mathrm{X}}^{+}\right)$. The geometries of various protonated and deprotonated states of the chromophore have been optimized using the $\mathrm{DFT}^{44-46}$ with the B3LYP functional. ${ }^{47,48}$ The basis set used is the $6-31 \mathrm{G}(\mathrm{d})$ set. ${ }^{49,50}$ For singlepoint calculations including electron correlations, the $\mathrm{SAC} /$ SAC-CI method is used. Basis sets of double zeta polarization (DZV) quality are used. The exponents are taken from Huzinaga et al. ${ }^{51}$ The Hartree-Fock (HF) SCF orbitals are used as the reference orbitals. The SAC/SAC-CI calculations are carried out with fullvalence active space for all the molecules studied here. The calculations of fluorescence energy, the geometries of the neutral form, two zwitterionic forms, and the anionic form in their excited states are optimized by the CIS method with the $6-31 \mathrm{G}(\mathrm{d})$ basis set. The polarization effect of protein on the excited states is estimated by a continuum model, ${ }^{39,40}$ using the refractive index of the ethanol solution (1.359), ${ }^{52}$ and the effective radius of the chromophore, treated as a spherical cavity, in various protonation states is calculated by DFT with the B3LYP functional for the ground-state geometry and by the CIS method for the excited-state geometry. The SAC-CI calculations are performed with the SAC-CI program in the development version of the GAUSSIAN program system. ${ }^{53}$ To reduce the computational cost, we use a perturbation selection procedure for two-electron excitation operators. ${ }^{54}$ For the ground state, the threshold of the linked term is set to $1 \times 10^{-5}$, and the unlinked terms are adopted as the products of the important linked terms whose CISD coefficients are larger than 0.001 . For the excited state, the threshold of the linked term is set to $1 \times 10^{-6}$. The thresholds for the unlinked terms in the SAC-CI are set to 0.001 and 0.05 , respectively, for selecting the important $S$ and $R$ operators, where only doubles, $S(2)$, are used from the SAC linked operators $S$. The contributions of both $S(2) R(1)$ and $S(2) R(2)$ unlinked operators are included. The other calculations, 
Table 1. Ground-State Energy (a.u.) of the GFP Chromophore in Its Various Protonation States.

\begin{tabular}{|c|c|c|c|}
\hline \multirow[b]{2}{*}{ Chromophore } & \multicolumn{2}{|c|}{ SAC } & \multirow{2}{*}{$\frac{\text { B3LYP }}{\text { Gas phase }}$} \\
\hline & Gas phase & + Solvation effect & \\
\hline \multicolumn{4}{|l|}{ (1) Neutral form } \\
\hline $\begin{array}{l}\left(\mathrm{HO}_{\mathrm{Y}}, \mathrm{N}, \mathrm{O}_{\mathrm{X}}\right) \\
\text { (2) Zwitterionic form }\end{array}$ & -681.48219 & -681.48293 & -685.15168 \\
\hline$\left(\mathrm{O}_{\mathrm{Y}}^{-}, \mathrm{N}, \mathrm{HO}_{\mathrm{X}}^{+}\right)$ & -681.44260 & -681.44922 & -685.10622 \\
\hline $\begin{array}{l}\left(\mathrm{O}_{\mathrm{Y}}^{-}, \mathrm{HN}^{+}, \mathrm{O}_{\mathrm{X}}\right) \\
\text { (3) Anionic form }\end{array}$ & -681.44898 & -681.45596 & -685.11646 \\
\hline $\begin{array}{c}\left(\mathrm{O}_{\mathrm{Y}}^{-}, \mathrm{N}, \mathrm{O}_{\mathrm{X}}\right)^{-} \\
\text {(4) Cationic form }\end{array}$ & -680.95127 & -680.95531 & -684.60551 \\
\hline$\left(\mathrm{HO}_{\mathrm{Y}}, \mathrm{HN}^{+}, \mathrm{O}_{\mathrm{X}}\right)^{+}$ & -681.85714 & -681.86081 & -685.53145 \\
\hline$\left(\mathrm{O}_{\mathrm{Y}}^{-}, \mathrm{HN}^{+}, \mathrm{HO}_{\mathrm{X}}^{+}\right)^{+}$ & -681.81263 & -681.82365 & -685.47830 \\
\hline$\left(\mathrm{HO}_{\mathrm{Y}}, \mathrm{N}, \mathrm{HO}_{\mathrm{X}}^{+}\right)^{+}$ & -681.85564 & -681.85748 & -685.51627 \\
\hline (5) Dicationic form & & & \\
\hline$\left(\mathrm{HO}_{\mathrm{Y}}, \mathrm{HN}^{+}, \mathrm{HO}_{\mathrm{X}}^{+}\right)^{2+}$ & -682.06540 & -682.06908 & -685.75771 \\
\hline
\end{tabular}

HF, DFT, and CIS, are carried out using the GAUSSIAN98 package. $^{55}$

\section{Results and Discussion}

\section{Ground-State Energy}

To assign ground-state protonation form, the correlated groundstate energies obtained by the SAC method for the GFPC in its various protonation states are summarized in Table 1 . The solvation effect is evaluated by the continuum model. The DFT results in the gas phase are also tabulated for comparison. Between the neutral and zwitterionic forms, the neutral form $\left(\mathrm{HO}_{\mathrm{Y}}, \mathrm{N}, \mathrm{O}_{\mathrm{X}}\right)$ is more stable by about $17 \mathrm{kcal} / \mathrm{mol}$, which is consistent with the $a b$ initio results due to Yazal et al. ${ }^{28}$ Deprotonation at the $\mathrm{O}_{\mathrm{Y}}$ position in the gas phase is endothermic. Among various cationic forms of the chromophore, $\left(\mathrm{HO}_{\mathrm{Y}}, \mathrm{HN}^{+}, \mathrm{O}_{\mathrm{X}}\right)^{+}$and $\left(\mathrm{HO}_{\mathrm{Y}}, \mathrm{N}, \mathrm{HO}_{\mathrm{X}}^{+}\right)^{+}$show comparable stability. The other cationic form $\left(\mathrm{O}_{\mathrm{Y}}, \mathrm{HN}, \mathrm{HO}_{\mathrm{X}}\right)^{+}$is relatively less stable. A cationic form $\left(\mathrm{HO}_{\mathrm{Y}}, \mathrm{N}, \mathrm{HO}_{\mathrm{X}}\right)^{+}$and a dicationic form $\left(\mathrm{HO}_{\mathrm{Y}}, \mathrm{HN}, \mathrm{HO}_{\mathrm{X}}\right)^{2+}$ of the chromophore have been reported to be chemically unstable. ${ }^{28}$ The present results suggest that the ionization of the phenyl group causes a large destabilization, which cannot be compensated for by the protonations at the $\mathrm{N}$ and $\mathrm{O}_{\mathrm{X}}$ sites. This result agrees with a previous experimental $\mathrm{p} K_{\mathrm{a}}$ measurement. ${ }^{17}$

\section{Excited States of the Chromophore in Its Various Protonation States}

We next study low- and high-lying singlet excited states of the GFPC in its various protonation states. The excitation energies, oscillator strengths, and dipole moments of the singlet excited states of all the protonation states of the chromophore are calculated by the SAC-CI method and the results are shown in Tables $2-5$. The fluorescence energies for the neutral, zwitterionic, and anionic states of the chromophore are given in Table 7. Other related theoretical and experimental values are also shown in each table. Table 8 gives a summary of the ground-state total energies and the excitation energies for all of the protonation states of the GFPC.

Among all of the protonation states, the $2{ }^{1} \mathrm{~A}^{\prime}$ state is the only state that has a strong oscillator strength. Therefore, our discussion in this article mainly focuses on the $2^{1} \mathrm{~A}^{\prime}$ state. The other excited states have much smaller intensity than the $2^{1} \mathrm{~A}^{\prime}$ state, and therefore can safely be neglected in assigning the absorption spectra. The main character of the $2^{1} \mathrm{~A}^{\prime}$ state is one-electron excitation from HOMO to LUMO. Both HOMO and LUMO are $\pi$ orbitals delocalized over the entire molecule, as shown in Figure 2. All of the other forms of the chromophore have very similar excited states and molecular orbitals.

The SAC/SAC-CI results for the neutral form $\left(\mathrm{HO}_{\mathrm{Y}}, \mathrm{N}, \mathrm{O}_{\mathrm{X}}\right)$ of the chromophore are summarized in Table 2 . The excitation energy and oscillator strength for the first excited state $2 \mathrm{~A}^{\prime}$ are computed to be $3.32 \mathrm{eV}$ and 0.73 a.u., respectively. Among the computed excited states up to $7 \mathrm{eV}$, the $2 \mathrm{~A}^{\prime}$ state has the largest oscillator strength. The solvent effect correction to the excitation energy is small, because the dipole moment is comparable to the ground state. At around $\mathrm{pH}=7$, the neutral form of the chromophore would be in solution. ${ }^{17,19,56}$ The observed peak at $3.33 \mathrm{eV} \cdot{ }^{17,19}$ is very close to our computed excitation energy. The semiempirical NDDO-G method gave an excitation energy of $3.43 \mathrm{eV}$, which is slightly higher than the SAC-CI values. ${ }^{19}$ The MCSCF/MCQDPT value in the gas phase $(2.88 \mathrm{eV})$ is much lower than ours. ${ }^{29}$ In the intact wild-type GFP, the chromophore in the A-form shows the absorption at $398 \mathrm{~nm}(3.13 \mathrm{eV})^{13}$ and the SAC-CI computed excitation energy for the $2^{1} \mathrm{~A}^{\prime}$ state is close to the experimental observation.

In the anionic form, $\left(\mathrm{O}_{\mathrm{Y}}, \mathrm{N}, \mathrm{O}_{\mathrm{X}}\right)^{-}$, the first excitation energy is calculated to be $2.22 \mathrm{eV}$ in the gas phase and $2.26 \mathrm{eV}$ in solution, as shown in Table 3. The dipole moment of the ground and first excited $\left(2^{1} \mathrm{~A}^{\prime}\right)$ states is much larger than that in the neutral form. In the wild-type GFP, the observed peak for the 
Table 2. Excitation Energy, Oscillator Strength, and Dipole Moment Calculated by the SAC/SAC-CI Method for the Singlet Excited States of GFP Chromophore in the Neutral Form $\left(\mathrm{HO}_{\mathrm{Y}}, \mathrm{N}, \mathrm{O}_{\mathrm{X}}\right)$.

\begin{tabular}{|c|c|c|c|c|c|c|c|c|}
\hline \multirow[b]{2}{*}{ State } & \multicolumn{6}{|c|}{ SAC-CI } & \multirow{2}{*}{$\begin{array}{c}\text { Other theory } \\
\mathrm{EE} \\
(\mathrm{eV})\end{array}$} & \multirow{2}{*}{$\begin{array}{c}\text { Exptl. } \\
\begin{array}{c}\text { EE } \\
(\mathrm{eV})\end{array}\end{array}$} \\
\hline & $\begin{array}{c}\mathrm{EE}(\mathrm{g})^{\mathrm{a}} \\
(\mathrm{eV})\end{array}$ & $\begin{array}{l}\mathrm{OS}(\mathrm{g})^{\mathrm{b}} \\
\text { (a.u.) }\end{array}$ & $\begin{array}{c}\operatorname{DM}(g)^{c} \\
(\text { a.u. })\end{array}$ & $\begin{array}{c}\Delta E(\mathrm{p})^{\mathrm{d}} \\
(\mathrm{eV})\end{array}$ & $\begin{array}{c}\Delta E \mathrm{C}(\mathrm{p})^{\mathrm{e}} \\
(\mathrm{eV})\end{array}$ & $\begin{array}{c}\mathrm{EE}(\mathrm{p})^{\mathrm{f}} \\
(\mathrm{eV})\end{array}$ & & \\
\hline \multicolumn{9}{|c|}{$\left(\mathrm{HO}_{\mathrm{Y}}, \mathrm{N}, \mathrm{O}_{\mathrm{X}}\right)$} \\
\hline $\mathrm{XA}^{\prime}$ & & & 1.86 & -0.02 & & & & \\
\hline $2 \mathrm{~A}^{\prime}$ & 3.33 & 0.7349 & 2.03 & -0.03 & -0.01 & 3.32 & $3.47^{\mathrm{g}}, 3.43^{\mathrm{h}}, 2.88^{\mathrm{i}}$ & $3.13^{\mathrm{j}},\left(3.33^{\mathrm{k}}\right)$ \\
\hline $3 \mathrm{~A}^{\prime}$ & 4.31 & 0.0293 & 2.15 & -0.03 & -0.01 & 4.30 & & \\
\hline $4 \mathrm{~A}^{\prime}$ & 4.79 & 0.0171 & 2.30 & -0.04 & -0.02 & 4.77 & & \\
\hline $5 \mathrm{~A}^{\prime}$ & 5.81 & 0.1931 & 2.85 & -0.05 & -0.03 & 5.78 & & \\
\hline $6 A^{\prime}$ & 6.03 & 0.0058 & 2.02 & -0.03 & -0.01 & 6.02 & & \\
\hline $7 \mathrm{~A}^{\prime}$ & 6.85 & 0.0860 & 2.22 & -0.03 & -0.01 & 6.84 & & \\
\hline $1 \mathrm{~A}^{\prime \prime}$ & 3.60 & 0.0008 & 2.86 & -0.05 & -0.03 & 3.57 & & \\
\hline $2 \mathrm{~A}^{\prime \prime}$ & 5.55 & 0.0009 & 2.80 & -0.05 & -0.03 & 5.52 & & \\
\hline $3 \mathrm{~A}^{\prime \prime}$ & 7.41 & 0.0003 & 4.14 & -0.11 & -0.09 & 7.32 & & \\
\hline $4 \mathrm{~A}^{\prime \prime}$ & 7.42 & 0.0033 & 2.48 & -0.04 & -0.02 & 7.40 & & \\
\hline
\end{tabular}

${ }^{\mathrm{a}}$ Excitation energy in the gas phase.

${ }^{\mathrm{b}}$ Oscillator strength in a.u.

${ }^{\mathrm{c}}$ Dipole moment in a.u.

${ }^{\mathrm{d}}$ Change in energy due to the polarization effect of protein by a continuum model.

${ }^{\mathrm{e}}$ Correction to excitation energy due to the polarization effect of protein by a continuum model.

${ }^{f}$ Excitation energy including the polarization effect of protein by a continuum model.

${ }^{\mathrm{g}} \mathrm{NDDO}-\mathrm{G}$ values in the gas phase, ref. 19.

${ }^{\mathrm{h}} \mathrm{NDDO}-\mathrm{G}$ value in ethanol, ref. 19.

${ }^{\mathrm{i}} \mathrm{MCSCF} / \mathrm{MCQDPT}$, ref. 29.

${ }^{\mathrm{j}}$ Intact wild-type GFP, ref. 13.

${ }^{\mathrm{k}}$ Model chromophore in solution under neutral conditions, ref. 19.

B-form $(478 \mathrm{~nm}, 2.60 \mathrm{eV}),{ }^{13}$ which was proposed to be the anionic form, ${ }^{17}$ is close to our SAC-CI excitation energy for the $2{ }^{1} \mathrm{~A}_{1}$ state. Recently, Andersen and coworkers measured absorption spectrum of the anion form in vacuo. ${ }^{23}$ The observed peak maximum was observed at $2.59 \mathrm{eV}$. The experimental model compound has an additional methyl group on $\mathrm{N}_{10}$ atom, although our computational model has, instead, $\mathrm{H}$ atom in this position. To compare directly with the experimental spectrum in vacuo, another SAC-CI calculation was carried out with the same structure as the experiment. As shown in Table 3, the obtained excitation energy was $2.39 \mathrm{eV}$, which is closer to the experimental value in the vacuo and also in protein. In solution at $\mathrm{pH} 8.2$, the model chromophore is transformed to the anionic form and the peak maximum is shifted to $2.68-2.90 \mathrm{eV} .{ }^{17,19,56}$ There seems to be a significant solvation effect in the experimental peak position, and most of the experiments used $\mathrm{NaOH}$ to obtain alkaline conditions. Our calculations used a simple dielectric model with the refractive index of ethanol. We note that our model is intended to mimic a protein environment, not an alkaline solution. To reproduce the excitation energy under alkaline condition, as in $\mathrm{NaOH}$ aq, an explicit modeling of the solvent would be required. The chromophore should be less solvated in the GFP protein than in $\mathrm{NaOH}$ aq.

Table 4 shows the excited states of the two zwitterionic forms, $\left(\mathrm{O}_{\mathrm{Y}}^{-}, \mathrm{N}, \mathrm{HO}_{\mathrm{X}}^{+}\right)$and $\left(\mathrm{O}_{\mathrm{Y}}^{-}, \mathrm{HN}^{+}, \mathrm{O}_{\mathrm{X}}\right)$. The first excited state of $\left(\mathrm{O}_{\mathrm{Y}}^{-}\right.$, $\mathrm{N}, \mathrm{HO}_{\mathrm{X}}^{+}$) is $1^{1} \mathrm{~A}^{\prime \prime}$, because the protonation on the oxygen atom $\mathrm{O}_{\mathrm{X}}$ reduces the HOMO-LUMO gap. However, the $2^{1} \mathrm{~A}^{\prime}$ state has much larger oscillator strength than the $1^{1} \mathrm{~A}^{\prime \prime}$ state. The excitation energy for the $2^{1} \mathrm{~A}^{\prime}$ state in the gas phase is calculated to be 3.13 and $2.15 \mathrm{eV}$ for $\left(\mathrm{O}_{\mathrm{Y}}^{-}, \mathrm{N}, \mathrm{HO}_{\mathrm{X}}^{+}\right)$and $\left(\mathrm{O}_{\mathrm{Y}}^{-}, \mathrm{HN}^{+}, \mathrm{O}_{\mathrm{X}}\right)$, respectively. Due to their charge distribution, these zwitterionic states have large dipole moments. The peak position shifts by -0.14 and $+0.05 \mathrm{eV}$ in $\left(\mathrm{O}_{\mathrm{Y}}^{-}, \mathrm{N}, \mathrm{HO}_{\mathrm{X}}^{+}\right)$and $\left(\mathrm{O}_{\mathrm{Y}}^{-}, \mathrm{HN}^{+}, \mathrm{O}_{\mathrm{X}}\right)$, respectively. So far, there is no evidence that the zwitterionic form is generated either in solution or in protein. However, in a recent hole-burning spectroscopic study, ${ }^{14}$ a new intermediate protonation state was predicted to be located in the lower-energy shoulder of the strong peak of the B-form. A previous semiempirical calculation showed that the zwitterionic $\left(\mathrm{O}_{\mathrm{Y}}^{-}, \mathrm{HN}^{+}, \mathrm{O}_{\mathrm{X}}\right)$ state has a strong peak in the lower-energy region of the B-form. ${ }^{19}$ The present SAC-CI result also shows that the $2^{1} \mathrm{~A}^{\prime}$ state appears at $2.20 \mathrm{eV}$, which is lower than that of the anionic form by only $0.06 \mathrm{eV}$. We note that the excitation energy of the $\left(\mathrm{O}_{\mathrm{Y}}^{-}, \mathrm{N}, \mathrm{HO}_{\mathrm{X}}^{+}\right)$form is very close to the absorption of the A-form in intact wild-type GFP, ${ }^{13}$ though this protonation form is much less stable than the neutral form, as seen in Table 1.

The SAC-CI results for the cationic forms, which are the most probable forms of the chromophore in an acidic $\mathrm{pH}$, are summarized in Table 5. There are three cationic forms, $\left(\mathrm{HO}_{\mathrm{Y}}\right.$, $\left.\mathrm{HN}^{+}, \mathrm{O}_{\mathrm{X}}\right)^{+},\left(\mathrm{O}_{\mathrm{Y}}^{-}, \mathrm{HN}^{+}, \mathrm{HO}_{\mathrm{X}}^{+}\right)^{+}$, and $\left(\mathrm{HO}_{\mathrm{Y}}, \mathrm{N}, \mathrm{HO}_{\mathrm{X}}^{+}\right)^{+}$, and $\mathrm{a}$ dicationic form, $\left(\mathrm{HO}_{\mathrm{Y}}, \mathrm{HN}^{+}, \mathrm{HO}_{\mathrm{X}}^{+}\right)^{2+}$. In the cationic and dicationic forms, the $2^{1} \mathrm{~A}^{\prime}$ state is the first excited state, except 
Table 3. Excitation Energy, Oscillator Strength, and Dipole Moment Calculated by the SAC/SAC-CI Method for the Singlet Excited States of GFP Chromophore in the Anionic Form.

\begin{tabular}{|c|c|c|c|c|c|c|c|c|}
\hline \multirow[b]{2}{*}{ State } & \multicolumn{6}{|c|}{ SAC-CI } & \multirow{2}{*}{$\begin{array}{c}\begin{array}{c}\text { Other } \\
\text { theory }\end{array} \\
\begin{array}{c}\mathrm{EE} \\
(\mathrm{eV})\end{array}\end{array}$} & \multirow{2}{*}{$\begin{array}{c}\text { Exptl. } \\
\begin{array}{c}\text { EE } \\
(\mathrm{eV})\end{array}\end{array}$} \\
\hline & $\begin{array}{c}\mathrm{EE}(\mathrm{g})^{\mathrm{a}} \\
(\mathrm{eV})\end{array}$ & $\begin{array}{l}\mathrm{OS}(\mathrm{g})^{\mathrm{b}} \\
\text { (a.u.) }\end{array}$ & $\begin{array}{l}\operatorname{DM}(\mathrm{g})^{\mathrm{c}} \\
\text { (a.u.) }\end{array}$ & $\begin{array}{l}\Delta E(\mathrm{p})^{\mathrm{d}} \\
(\mathrm{eV})\end{array}$ & $\begin{array}{l}\Delta E \mathrm{C}(\mathrm{p})^{\mathrm{e}} \\
(\mathrm{eV})\end{array}$ & $\begin{array}{c}\mathrm{EE}(\mathrm{p})^{\mathrm{f}} \\
(\mathrm{eV})\end{array}$ & & \\
\hline \multicolumn{9}{|c|}{$\left(\mathrm{O}_{\mathrm{Y}}, \mathrm{N}, \mathrm{O}_{\mathrm{X}}\right)^{-}$} \\
\hline $\mathrm{XA}^{\prime}$ & & & 4.06 & -0.11 & & & & \\
\hline $2 \mathrm{~A}^{\prime}$ & 2.22 & 0.8345 & 3.25 & -0.07 & +0.04 & 2.26 & $\begin{array}{c}2.70^{\mathrm{g}}, 2.86^{\mathrm{h}} \\
\quad 4.37^{\mathrm{i}}\end{array}$ & $\begin{array}{c}2.60^{\mathrm{i}}, 2.59^{\mathrm{k}},\left(2.76^{\mathrm{l}}\right) \\
\left(2.90^{\mathrm{m}}, 2.78^{\mathrm{n}}, 2.68^{\mathrm{o}}\right)\end{array}$ \\
\hline $3 \mathrm{~A}^{\prime}$ & 3.95 & 0.0695 & 5.82 & -0.23 & -0.12 & 3.83 & & \\
\hline $4 \mathrm{~A}^{\prime}$ & 4.49 & 0.0033 & 4.34 & -0.13 & -0.02 & 4.47 & & \\
\hline $5 \mathrm{~A}^{\prime}$ & 4.76 & 0.0444 & 1.69 & -0.02 & +0.09 & 4.85 & & \\
\hline $6 \mathrm{~A}^{\prime}$ & 5.08 & 0.1241 & 1.11 & -0.01 & +0.10 & 5.18 & & \\
\hline $7 A^{\prime}$ & 5.61 & 0.0130 & 3.66 & -0.09 & +0.02 & 5.63 & & \\
\hline $1 \mathrm{~A}^{\prime \prime}$ & 3.49 & 0.0000 & 1.85 & -0.01 & +0.10 & 3.59 & & \\
\hline $2 \mathrm{~A}^{\prime \prime}$ & 4.32 & 0.0010 & 7.14 & -0.05 & +0.06 & 4.38 & & \\
\hline $3 \mathrm{~A}^{\prime \prime}$ & 6.24 & 0.0021 & 5.39 & -0.04 & +0.07 & 6.31 & & \\
\hline \multicolumn{9}{|c|}{$\left(\mathrm{O}_{\mathrm{Y}}, \mathrm{N}, \mathrm{O}_{\mathrm{X}}\right)^{-}$with methyl group } \\
\hline $2 \mathrm{~A}^{\prime}$ & 2.39 & 0.8869 & & & & & & $\begin{array}{c}2.60^{\mathrm{i}}, 2.59^{\mathrm{k}},\left(2.76^{\mathrm{l}}\right) \\
\left(2.90^{\mathrm{m}}, 2.78^{\mathrm{n}}, 2.68^{\mathrm{o}}\right)\end{array}$ \\
\hline $3 \mathrm{~A}^{\prime}$ & 3.99 & 0.0770 & & & & & & \\
\hline
\end{tabular}

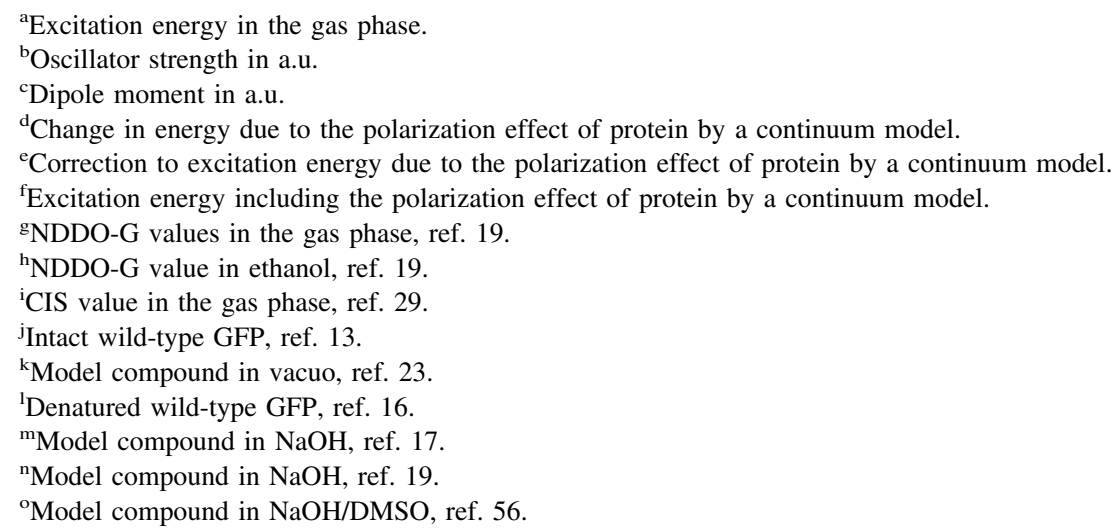

for the $1^{1} \mathrm{~A}^{\prime \prime}$ state of the $\left(\mathrm{O}_{\mathrm{Y}}^{-}, \mathrm{HN}^{+}, \mathrm{HO}_{\mathrm{X}}^{+}\right)^{+}$form, which is lower than the $2^{1} \mathrm{~A}^{\prime}$ state by $0.8 \mathrm{eV}$. The HOMO $\rightarrow$ LUMO excitation has the largest transition moment in all of the cationic and dicationic protonation states. In the study of the model compound in acidic solution, the chromophore showed the absorption at $3.05-3.15 \mathrm{eV} .{ }^{17,19}$ In the present study, the excitation energies for the $2{ }^{1} \mathrm{~A}^{\prime}$ states of the $\left(\mathrm{HO}_{\mathrm{Y}}, \mathrm{HN}^{+}, \mathrm{O}_{\mathrm{X}}\right)^{+}$and $\left(\mathrm{O}_{\mathrm{Y}}^{-}, \mathrm{HN}^{+}, \mathrm{HO}_{\mathrm{X}}^{+}\right)^{+}$forms are calculated to be 2.71 and $3.29 \mathrm{eV}$, respectively. In a previous study, Yazal et al. ${ }^{28}$ also pointed out by $\mathrm{p} K_{\mathrm{a}}$ calculations that the chromophore is mainly in the cationic forms $\left(\mathrm{HO}_{\mathrm{Y}}, \mathrm{HN}, \mathrm{O}_{\mathrm{X}}\right)^{+}$and $\left(\mathrm{O}_{\mathrm{Y}}^{-}, \mathrm{HN}^{+}, \mathrm{HO}_{\mathrm{X}}\right)^{+}$under acidic $\mathrm{pH}$. However, the ground state of the former form is more stable than that of the latter by $23 \mathrm{kcal} / \mathrm{mol}$ at the correlated SAC level. Further, deprotonation at the $\mathrm{O}_{\mathrm{Y}}$ position would not be realistic in acidic solution. Therefore, the groundstate protonation form in an acidic solution is assigned to $\left(\mathrm{HO}_{\mathrm{Y}}\right.$, $\left.\mathrm{HN}^{+}, \mathrm{O}_{\mathrm{X}}\right)^{+}$form. The same assignment was proposed by the semiempirical study. ${ }^{19}$ Recently, Andersen and coworkers measured absorption spectrum of the cation form in vacuo. ${ }^{24}$ The observed peak maximum was observed at $3.05 \mathrm{eV}$. The experimental compound has an additional methyl group on $\mathrm{N}_{10}$ atom, although our computational model has, instead, $\mathrm{H}$ atom in this position. To compare directly with the experimental spectrum in vacuo, another SAC-CI calculation was carried out for the $\left(\mathrm{HO}_{\mathrm{Y}}, \mathrm{HN}^{+}, \mathrm{O}_{\mathrm{X}}\right)^{+}$form with the same structure as the experiment. The obtained excitation energy was $2.88 \mathrm{eV}$, which is closer to the experimental value in vacuo and also in the acidic solution.

Analysis of the Stark spectrum provides the change in the dipole moment associated with the transition. ${ }^{13,57}$ Table 6 lists electronic dipole moments of the anionic and neutral forms of the chromophore in the ground and excited states. For the anionic form, the SAC-CI calculation gave 2.2 debye, while the experiments gave 6.2 debye. There are several anionic (Glu222) and 
Table 4. Excitation Energy, Oscillator Strength, and Dipole Moment Calculated by the SAC/SAC-CI Method for the Singlet Excited States of GFP Chromophore in the Zwitterionic Form.

\begin{tabular}{|c|c|c|c|c|c|c|c|}
\hline \multirow[b]{2}{*}{ State } & \multicolumn{6}{|c|}{ SAC-CI } & \multirow{2}{*}{$\begin{array}{c}\begin{array}{c}\text { Other } \\
\text { theory }\end{array} \\
\begin{array}{c}\mathrm{EE} \\
(\mathrm{eV})\end{array}\end{array}$} \\
\hline & $\begin{array}{c}\mathrm{EE}(\mathrm{g})^{\mathrm{a}} \\
(\mathrm{eV})\end{array}$ & $\begin{array}{l}\mathrm{OS}(\mathrm{g})^{\mathrm{b}} \\
\text { (a.u.) }\end{array}$ & $\begin{array}{c}\operatorname{DM}(\mathrm{g})^{\mathrm{c}} \\
(\text { a.u. })\end{array}$ & $\begin{array}{c}\Delta E(\mathrm{p})^{\mathrm{d}} \\
(\mathrm{eV})\end{array}$ & $\begin{array}{c}\Delta E \mathrm{C}(\mathrm{p})^{\mathrm{e}} \\
(\mathrm{eV})\end{array}$ & $\begin{array}{c}\mathrm{EE}(\mathrm{p})^{\mathrm{f}} \\
(\mathrm{eV})\end{array}$ & \\
\hline \multicolumn{8}{|c|}{$\left(\mathrm{O}_{\mathrm{Y}}^{-}, \mathrm{N}, \mathrm{HO}_{\mathrm{X}}^{+}\right)$} \\
\hline $\mathrm{XA}^{\prime}$ & & & 5.33 & -0.18 & & & \multirow{6}{*}{$3.29^{\mathrm{g}}, 2.93^{\mathrm{h}}$} \\
\hline $2 \mathrm{~A}^{\prime}$ & 3.13 & 1.0072 & 7.07 & -0.32 & -0.14 & 2.99 & \\
\hline $3 \mathrm{~A}^{\prime}$ & 4.20 & 0.0123 & 3.96 & -0.10 & +0.08 & 4.28 & \\
\hline $4 \mathrm{~A}^{\prime}$ & 4.82 & 0.0649 & 6.55 & -0.28 & -0.10 & 4.72 & \\
\hline $5 A^{\prime}$ & 5.05 & 0.0208 & 6.99 & -0.32 & -0.14 & 4.91 & \\
\hline $6 \mathrm{~A}^{\prime}$ & 5.64 & 0.1488 & 3.40 & -0.08 & +0.10 & 5.74 & \\
\hline $1 A^{\prime \prime}$ & 2.77 & 0.0008 & 2.18 & -0.03 & +0.15 & 2.92 & \multirow{15}{*}{$2.62^{\mathrm{g}}, 2.79^{\mathrm{h}}$} \\
\hline $2 \mathrm{~A}^{\prime \prime}$ & 5.90 & 0.0009 & 8.12 & -0.42 & -0.24 & 5.66 & \\
\hline $3 \mathrm{~A}^{\prime \prime}$ & 5.97 & 0.0003 & 1.42 & -0.01 & +0.17 & 6.14 & \\
\hline $4 A^{\prime \prime}$ & 6.47 & 0.0033 & 5.29 & -0.18 & 0.00 & 6.47 & \\
\hline \multicolumn{8}{|c|}{$\left(\mathrm{O}_{\mathrm{Y}}^{-}, \mathrm{HN}^{+}, \mathrm{O}_{\mathrm{X}}\right)$} \\
\hline $\mathrm{XA}^{\prime}$ & & & 5.34 & -0.19 & & & \\
\hline $2 \mathrm{~A}^{\prime}$ & 2.15 & 0.7622 & 4.45 & -0.14 & +0.05 & 2.20 & \\
\hline $3 \mathrm{~A}^{\prime}$ & 3.78 & 0.1917 & 2.94 & -0.06 & +0.13 & 3.91 & \\
\hline $4 \mathrm{~A}^{\prime}$ & 4.44 & 0.0286 & 3.51 & -0.09 & +0.10 & 4.54 & \\
\hline $5 \mathrm{~A}^{\prime}$ & 4.50 & 0.0487 & 3.89 & -0.11 & +0.08 & 4.58 & \\
\hline $6 \mathrm{~A}^{\prime}$ & 4.66 & 0.0779 & 7.29 & -0.37 & -0.18 & 4.48 & \\
\hline $7 \mathrm{~A}^{\prime}$ & 5.77 & 0.0095 & 5.87 & -0.24 & -0.05 & 5.72 & \\
\hline $1 \mathrm{~A}^{\prime \prime}$ & 2.89 & 0.0000 & 3.04 & -0.06 & +0.13 & 3.02 & \\
\hline $2 \mathrm{~A}^{\prime \prime}$ & 4.83 & 0.0001 & 8.03 & -0.44 & -0.25 & 4.58 & \\
\hline $3 \mathrm{~A}^{\prime \prime}$ & 5.18 & 0.0001 & 4.19 & -0.12 & +0.07 & 5.25 & \\
\hline $4 A^{\prime \prime}$ & 5.41 & 0.0001 & 2.21 & -0.03 & +0.16 & 5.57 & \\
\hline
\end{tabular}

${ }^{\mathrm{a}}$ Excitation energy in the gas phase.

${ }^{\mathrm{b}}$ Oscillator strength in a.u.

${ }^{\mathrm{c}}$ Dipole moment in a.u.

${ }^{\mathrm{d}}$ Change in energy due to the polarization effect of protein by a continuum model.

${ }^{\mathrm{e}}$ Correction to excitation energy due to the polarization effect of protein by a continuum model.

${ }^{f}$ Excitation energy including the polarization effect of protein by a continuum model.

${ }^{\mathrm{g}} \mathrm{NDDO}-\mathrm{G}$ values in the gas phase, ref. 19.

${ }^{\mathrm{h}} \mathrm{NDDO}-\mathrm{G}$ value in ethanol, ref. 19.

cationic (Arg96) residues in the proximity of the chromophore, which can affect to the dipole moment of the states. The present calculations, however, include the environmental effect only by a simple continuum model.

\section{Fluorescence Energy in Several Protonation Forms}

The calculation of the fluorescence energy is important for this system to determine the protonation form of the ground state. The SAC/SAC-CI calculations were performed at the geometries optimized for the $2^{1} \mathrm{~A}^{\prime}$ state of the neutral, anionic, and zwitterionic forms. The cationic forms were disregarded, because the GFP protein does not take a strong acidic form that can protonate at the $\mathrm{N}$ and $\mathrm{O}_{\mathrm{X}}$ positions of the chromophore. The geometrical changes in the excited states of these protonation states of the chromophore were not large. The chromophore nearly keeps the $\mathrm{C}_{\mathrm{s}}$ symmetry in all of the protonation forms. For the neutral form, $\mathrm{C}_{7}-\mathrm{C}_{8}$ bond stretched by $0.055 \AA$, which was the largest change. This bond stretching is relevant to the character of LUMO. As shown in Figure 2, LUMO has a node in the $\mathrm{C}_{7}-\mathrm{C}_{8}$ bond. For the anionic form, the $\mathrm{C}_{8}-\mathrm{N}_{13}$ and the $\mathrm{C}_{9}-\mathrm{N}_{10}$ bonds shrank by $0.030 \AA$, which is also rationalized by the orbital character of HOMO and LUMO. The obtained structural parameters were also compared to those reported in a previous article. ${ }^{29}$ These optimized structures were very close to each other, and the deviation in the bond length was within $0.02 \AA$.

The fluorescence energies in the gas phase and in the continuum model are shown in Table 7, along with those from the experiment on the intact wild-type $\mathrm{GFP}^{13}$ and from the UHF/MP2 calculation. ${ }^{29}$ In all of the protonation states, the $2^{1} \mathrm{~A}_{1}$ state is characterized to be HOMO to LUMO excitation. The fluorescence intensity of the $2^{1} \mathrm{~A}_{1}$ state is the largest of all the excited states in each protonation state. The zwitterionic forms show a relatively large solvation effect. 
Table 5. Excitation Energy, Oscillator Strength, and Dipole Moment Calculated by the SAC/SAC-CI Method for the Singlet Excited States of GFP Chromophore in the Cationic and Dicationic Forms.

\begin{tabular}{|c|c|c|c|c|c|c|c|c|}
\hline \multirow[b]{2}{*}{ State } & \multicolumn{6}{|c|}{ SAC-CI } & \multirow{2}{*}{$\begin{array}{c}\begin{array}{c}\text { Other } \\
\text { theory }\end{array} \\
\begin{array}{c}\mathrm{EE} \\
(\mathrm{eV})\end{array}\end{array}$} & \multirow{2}{*}{$\begin{array}{c}\text { Exptl. } \\
\begin{array}{c}\text { EE } \\
(\mathrm{eV})\end{array}\end{array}$} \\
\hline & $\begin{array}{c}\mathrm{EE}(\mathrm{g})^{\mathrm{a}} \\
(\mathrm{eV})\end{array}$ & $\begin{array}{c}\mathrm{OS}(\mathrm{g})^{\mathrm{b}} \\
\text { (a.u.) }\end{array}$ & $\begin{array}{c}\mathrm{DM}(\mathrm{g})^{\mathrm{c}} \\
\text { (a.u.) }\end{array}$ & $\begin{array}{c}\Delta E(\mathrm{p})^{\mathrm{d}} \\
(\mathrm{eV})\end{array}$ & $\begin{array}{c}\Delta E \mathrm{C}(\mathrm{p})^{\mathrm{e}} \\
(\mathrm{eV})\end{array}$ & $\begin{array}{c}\mathrm{EE}(\mathrm{p})^{\mathrm{f}} \\
(\mathrm{eV})\end{array}$ & & \\
\hline \multicolumn{9}{|c|}{$\left(\mathrm{HO}_{\mathrm{Y}}, \mathrm{HN}^{+}, \mathrm{O}_{\mathrm{X}}\right)^{+}$} \\
\hline $\mathrm{XA}^{\prime}$ & & & 3.86 & -0.10 & & & & \\
\hline $2 \mathrm{~A}^{\prime}$ & 2.68 & 0.7036 & 3.10 & -0.07 & +0.03 & 2.71 & $3.07^{\mathrm{g}}, 3.41^{\mathrm{h}}$ & $3.05^{\mathrm{i}},\left(3.05^{\mathrm{j}}, 3.15^{\mathrm{k}}\right)$ \\
\hline $3 \mathrm{~A}^{\prime}$ & 3.95 & 0.0012 & 3.10 & -0.07 & +0.03 & 3.98 & & \\
\hline $1 \mathrm{~A}^{\prime \prime}$ & 3.95 & 0.0002 & 4.77 & -0.16 & -0.06 & 3.89 & & \\
\hline $4 \mathrm{~A}^{\prime}$ & 4.87 & 0.0538 & 2.86 & -0.06 & +0.04 & 4.91 & & \\
\hline \multicolumn{9}{|c|}{$\left(\mathrm{HO}_{\mathrm{Y}}, \mathrm{HN}^{+}, \mathrm{O}_{\mathrm{X}}\right)^{+}$with methyl group } \\
\hline $2 \mathrm{~A}^{\prime}$ & 2.88 & 0.5524 & & & & & & $3.05^{\mathrm{i}},\left(3.05^{\mathrm{j}}, 3.15^{\mathrm{k}}\right)$ \\
\hline $3 \mathrm{~A}^{\prime}$ & 4.09 & 0.0036 & & & & & & \\
\hline \multicolumn{9}{|c|}{$\left(\mathrm{O}_{\mathrm{Y}}^{-}, \mathrm{HN}^{+}, \mathrm{HO}_{\mathrm{X}}^{+}\right)^{+}$} \\
\hline $\mathrm{XA}^{\prime}$ & & & 6.78 & -0.30 & & & & \\
\hline $1 \mathrm{~A}^{\prime \prime}$ & 2.42 & 0.0000 & 3.84 & -0.01 & +0.29 & 2.71 & & \\
\hline $2 \mathrm{~A}^{\prime}$ & 3.24 & 0.9089 & 5.92 & -0.25 & +0.05 & 3.29 & $3.27^{\mathrm{g}}, 2.95^{\mathrm{h}}$ & \\
\hline $3 \mathrm{~A}^{\prime}$ & 4.04 & 0.0262 & 5.09 & -0.18 & +0.12 & 4.16 & & \\
\hline $4 \mathrm{~A}^{\prime}$ & 4.47 & 0.2899 & 4.17 & -0.12 & +0.18 & 4.65 & & \\
\hline $5 \mathrm{~A}^{\prime}$ & 4.94 & 0.0283 & 6.90 & -0.32 & -0.02 & 4.92 & & \\
\hline \multicolumn{9}{|c|}{$\left(\mathrm{HO}_{\mathrm{Y}}, \mathrm{N}, \mathrm{HO}_{\mathrm{X}}^{+}\right)^{+}$} \\
\hline $\mathrm{XA}^{\prime}$ & & & 2.74 & -0.05 & & & & \\
\hline $2 \mathrm{~A}^{\prime}$ & 2.39 & 0.7564 & 1.95 & -0.03 & +0.02 & 2.41 & $2.82^{\mathrm{g}}, 3.05^{\mathrm{h}}$ & \\
\hline $3 \mathrm{~A}^{\prime}$ & 3.42 & 0.0212 & 0.15 & -0.00 & +0.05 & 3.47 & & \\
\hline $4 \mathrm{~A}^{\prime}$ & 4.13 & 0.0052 & 3.89 & -0.10 & -0.05 & 4.08 & & \\
\hline $1 \mathrm{~A}^{\prime \prime}$ & 4.22 & 0.0002 & 5.32 & -0.19 & -0.14 & 4.08 & & \\
\hline \multicolumn{9}{|c|}{$\left(\mathrm{HO}_{\mathrm{Y}}, \mathrm{HN}^{+}, \mathrm{HO}_{\mathrm{X}}^{+}\right)^{2+}$} \\
\hline $\mathrm{XA}^{\prime}$ & & & 3.79 & -0.10 & & & & \\
\hline $2 \mathrm{~A}^{\prime}$ & 2.43 & 0.8138 & 3.45 & -0.08 & +0.02 & 2.45 & $2.93^{\mathrm{g}}, 3.00^{\mathrm{h}}$ & \\
\hline $3 \mathrm{~A}^{\prime}$ & 2.98 & 0.0654 & 1.95 & -0.03 & +0.07 & 3.05 & & \\
\hline $1 \mathrm{~A}^{\prime \prime}$ & 3.49 & 0.0000 & 1.85 & -0.01 & +0.10 & 3.59 & & \\
\hline $2 \mathrm{~A}^{\prime \prime}$ & 4.32 & 0.0010 & 7.14 & -0.05 & +0.06 & 4.38 & & \\
\hline $4 \mathrm{~A}^{\prime}$ & 4.53 & 0.0093 & 4.09 & -0.11 & -0.01 & 4.52 & & \\
\hline
\end{tabular}

${ }^{\mathrm{a} E x c i t a t i o n}$ energy in the gas phase.

${ }^{\mathrm{b}}$ Oscillator strength in a.u.

${ }^{\mathrm{c}}$ Dipole moment in a.u.

${ }^{\mathrm{d}}$ Change in energy due to the polarization effect of protein by a continuum model.

${ }^{e}$ Correction to excitation energy due to the polarization effect of protein by a continuum model.

${ }^{\mathrm{f}}$ Excitation energy including the polarization effect of protein by a continuum model.

${ }^{\mathrm{g}} \mathrm{NDDO}-\mathrm{G}$ values in the gas phase, ref. 19.

${ }^{\mathrm{h}} \mathrm{NDDO}-\mathrm{G}$ value in ethanol, ref. 19.

${ }^{\mathrm{i}}$ Model chromophore in vacuo, ref. 24.

${ }^{\mathrm{j}}$ Model chromophore in $\mathrm{HCl}$ aq, ref. 19.

${ }^{\mathrm{k}}$ Model chromophore in $\mathrm{HCl}$ aq, ref. 17.

Among the four forms of the chromophore, our calculated fluorescence energies for the neutral $\left(\mathrm{HO}_{\mathrm{Y}}, \mathrm{N}, \mathrm{O}_{\mathrm{X}}\right)$ and zwitterionic $\left(\mathrm{O}_{\mathrm{Y}}^{-}, \mathrm{N}, \mathrm{HO}_{\mathrm{X}}^{+}\right)$forms are very close to the experimental value for the A-form of intact wild-type GFP $(2.64-2.95 \mathrm{eV}){ }^{13} \mathrm{~A}$ previous UHF/MP2 calculation ${ }^{29}$ for the neutral form gave a value that was lower than both the experimental value and our present calculated value. Our predicted fluorescence energies for the anionic form $\left(\mathrm{O}_{\mathrm{Y}}, \mathrm{N}, \mathrm{O}_{\mathrm{X}}\right)^{-}$and the zwitterionic form $\left(\mathrm{O}_{\mathrm{Y}}^{-}, \mathrm{HN}^{+}\right.$, $\mathrm{HO}_{\mathrm{X}}$ ) of the chromophore are close to the experimental value for green fluorescence $(2.44 \mathrm{eV})$. The previous $\mathrm{UHF} / \mathrm{MP} 2$ value $^{29}$ is much higher.

\section{Assignment of the Ground-State Protonation State Based on the SAC-CI Results}

According to the previous studies on the model compound in solution, ${ }^{17,19}$ the absorption peaks at 3.13 (A-form) and $2.60 \mathrm{eV}$ (B-form) in the intact wild-type $\mathrm{GFP}^{13}$ were assigned to neutral 
Table 6. Electronic Dipole Moment of the Ground and Excited States of GFP Chromophore in the Neutral and Anion States.

\begin{tabular}{lccccc}
\hline & \multicolumn{4}{c}{ SAC-CI (debye) } & \\
\cline { 2 - 5 } State & $|\mu|$ & $x^{\mathrm{b}}$ & $y^{\mathrm{b}}$ & $z^{\mathrm{b}}$ & $\begin{array}{c}\text { Exptl. }^{\mathrm{a}} \\
\text { debye }^{\mathrm{b}}\end{array}$ \\
\hline \multicolumn{2}{l}{ Neutral form $\left(\mathrm{HO}_{\mathrm{Y}}, \mathrm{N}, \mathrm{O}_{\mathrm{X}}\right)$} & & & & \\
$\quad$ Ground & 4.72 & 2.34 & -4.12 & 0.0 & \\
1 -st Excited & 5.17 & 0.13 & -5.16 & 0.0 & \\
$|\Delta \mu|$ & 2.45 & -2.21 & -1.07 & 0.0 & \\
Anion form $\left(\mathrm{O}_{\mathrm{Y}}^{-}, \mathrm{N}, \mathrm{O}_{\mathrm{X}}\right)^{-}$ & & & & \\
Ground & 10.32 & 10.29 & -0.56 & 0.0 & \\
1-st Excited & 8.25 & 8.18 & -0.99 & 0.0 & \\
$|\Delta \mu|$ & 2.15 & -2.11 & -0.43 & 0.0 & 6.2 \\
\hline
\end{tabular}

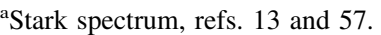

${ }^{\mathrm{b}}$ The reference coordinate is indicated in Figure 1.

$\left(\mathrm{HO}_{\mathrm{Y}}, \mathrm{N}, \mathrm{O}_{\mathrm{X}}\right)$ and anionic $\left(\mathrm{O}_{\mathrm{Y}}, \mathrm{N}, \mathrm{O}_{\mathrm{X}}\right)^{-}$forms, respectively. Table 8 summarizes all of the calculated data that might be useful for the assignment of the ground-state protonation form. As described above, our SAC-CI excitation energies for the neutral and zwitterionic $\left(\mathrm{O}_{\mathrm{Y}}^{-}, \mathrm{N}, \mathrm{HO}_{\mathrm{X}}^{+}\right)$forms are 3.32 and $2.99 \mathrm{eV}$, respectively, which are relatively close to the A-form absorption. The fluorescence energies for these neutral and zwitterionic states are 2.82 and $2.92 \mathrm{eV}$, which are also close to the experimental fluorescence energy. ${ }^{13}$ The Stokes shift computed for the neutral form is $0.5 \mathrm{eV}$, which is comparable to the observed value, $0.43 \mathrm{eV}$. Based on the calculated results, the neutral form is most appropriately assigned to the experimental A-form rather than the zwitterionic form. In addition, from a chemical point of view, the zwitterionic form, $\left(\mathrm{O}_{\mathrm{Y}}^{-}, \mathrm{N}, \mathrm{HO}_{\mathrm{X}}^{+}\right)$, is much less stable than the neutral form. ${ }^{28}$ Further, in the proximity of the $\mathrm{O}_{\mathrm{X}}$ site, there is no strongly acidic residue that can protonate to the $\mathrm{O}_{\mathrm{X}}$ position. ${ }^{26}$

Regarding the experimental B-form absorption $(2.60 \mathrm{eV})$, the anionic and zwitterionic $\left(\mathrm{O}_{\mathrm{Y}}^{-}, \mathrm{HN}^{+}, \mathrm{O}_{\mathrm{X}}\right)$ forms are the

Table 7. Fluorescence Energy for the GFP Chromophore in Its Neutral, Zwitterionic, and Anionic Forms.

\begin{tabular}{|c|c|c|c|c|c|c|c|c|}
\hline \multirow[b]{2}{*}{ State } & \multicolumn{6}{|c|}{ SAC-CI } & \multirow{2}{*}{$\begin{array}{c}\begin{array}{c}\text { Other } \\
\text { theory }\end{array} \\
\begin{array}{c}\mathrm{EF} \\
(\mathrm{eV})\end{array}\end{array}$} & \multirow{2}{*}{$\begin{array}{c}\text { Exptl. } \\
\begin{array}{c}\mathrm{EF} \\
(\mathrm{eV})\end{array}\end{array}$} \\
\hline & $\begin{array}{c}\mathrm{EF}(\mathrm{g})^{\mathrm{a}} \\
(\mathrm{eV})\end{array}$ & $\begin{array}{l}\mathrm{FI}(\mathrm{g})^{\mathrm{b}} \\
\text { (a.u.) }\end{array}$ & $\begin{array}{c}\operatorname{DM}(\mathrm{g})^{\mathrm{c}} \\
\text { (a.u.) }\end{array}$ & $\begin{array}{c}\Delta E(\mathrm{p})^{\mathrm{d}} \\
(\mathrm{eV})\end{array}$ & $\begin{array}{c}\Delta E \mathrm{C}(\mathrm{p})^{\mathrm{e}} \\
(\mathrm{eV})\end{array}$ & $\begin{array}{c}\mathrm{EF}(\mathrm{p})^{\mathrm{f}} \\
(\mathrm{eV})\end{array}$ & & \\
\hline \multicolumn{9}{|c|}{ Neutral form $\left(\mathrm{HO}_{\mathrm{Y}}, \mathrm{N}, \mathrm{O}_{\mathrm{X}}\right)$} \\
\hline $\begin{array}{l}\mathrm{XA}^{\prime} \\
2 \mathrm{~A}^{\prime} \\
\text { Zwitte }\end{array}$ & $\begin{array}{c}2.82 \\
\mathrm{~cm}\left(\mathrm{O}_{\mathrm{Y}}^{-},\right.\end{array}$ & 0.73 & $\begin{array}{l}1.84 \\
1.94\end{array}$ & $\begin{array}{l}-0.02 \\
-0.02\end{array}$ & 0.00 & 2.82 & $2.53^{\mathrm{g}}$ & $2.64-2.95^{\mathrm{h}}$ \\
\hline $\begin{array}{l}X A^{\prime} \\
2 A^{\prime} \\
Z w i t t e\end{array}$ & $\begin{array}{c}2.83 \\
\mathrm{~m}\left(\mathrm{O}_{\mathrm{Y}}^{-},\right.\end{array}$ & 1.02 & $\begin{array}{l}5.78 \\
6.68\end{array}$ & $\begin{array}{l}-0.31 \\
-0.22\end{array}$ & +0.09 & 2.92 & & \\
\hline $\begin{array}{l}\mathrm{XA}^{\prime} \\
2 \mathrm{~A}^{\prime} \\
\text { Anion }\end{array}$ & $\begin{array}{c}1.92 \\
\mathrm{O}_{\mathrm{Y}}^{-}, \mathrm{N}, \mathrm{C}\end{array}$ & 0.67 & $\begin{array}{l}5.60 \\
3.93\end{array}$ & $\begin{array}{l}-0.21 \\
-0.10\end{array}$ & +0.11 & 2.03 & & \\
\hline $\begin{array}{l}\mathrm{XA}^{\prime} \\
2 \mathrm{~A}^{\prime}\end{array}$ & 2.14 & 0.79 & $\begin{array}{l}3.88 \\
3.30\end{array}$ & $\begin{array}{l}-0.09 \\
-0.06\end{array}$ & +0.03 & 2.17 & $2.97^{\mathrm{g}}$ & $2.44^{\mathrm{h}}$ \\
\hline
\end{tabular}

${ }^{\mathrm{a}}$ Fluorescence energy in the gas phase.

${ }^{b}$ Fluorescence intensity in a.u.

${ }^{\mathrm{c}}$ Dipole moment of the state in a.u.

${ }^{\mathrm{d}}$ Change in energy due to the polarization effect of protein by a continuum model.

${ }^{\text {e }}$ Correction to fluorescence energy due to the polarization effect of protein by a continuum model.

${ }^{\mathrm{f}}$ Fluorescence energy including the polarization effect of protein by a continuum model.

${ }^{\mathrm{g}} \mathrm{UHF} / \mathrm{MP} 2$ in the gas phase, ref. 29.

${ }^{\mathrm{h}}$ Intact wild-type GFP, ref. 13. 
Table 8. Ground-State Total Energy, Excitation Energy, and Fluorescence Energy of the GFP Chromophore in Its Various Protonation States.

\begin{tabular}{|c|c|c|c|c|c|c|c|c|c|c|}
\hline \multirow[b]{3}{*}{ Protonation state } & \multicolumn{8}{|c|}{ Theoretical } & \multirow{2}{*}{\multicolumn{2}{|c|}{$\frac{\text { Experimental }}{\text { Wild-type }^{\mathrm{c}}}$}} \\
\hline & \multicolumn{5}{|c|}{ SAC/SAC-CI (present study) } & \multirow{2}{*}{$\frac{\mathrm{NDDO}^{\mathrm{a}} \mathrm{G}^{\mathrm{a}}}{E_{\mathrm{abs}}}$} & \multicolumn{2}{|c|}{ MCQDPT $^{\mathrm{b}}$} & & \\
\hline & $E_{g}^{\mathrm{d}}$ & $E_{\mathrm{abs}}{ }^{\mathrm{e}}$ & $f_{\text {abs }}{ }^{\mathrm{f}}$ & $E_{f}^{\mathrm{g}}$ & $f_{f}^{\mathrm{h}}$ & & $E_{\mathrm{abs}}$ & $E_{f}$ & $E_{\mathrm{abs}}$ & $E_{f}$ \\
\hline \multicolumn{11}{|l|}{ (1) Neutral form } \\
\hline $\begin{array}{l}\left(\mathrm{HO}_{\mathrm{Y}}, \mathrm{N}, \mathrm{O}_{\mathrm{X}}\right) \\
\text { (2) Zwitterionic form }\end{array}$ & -681.48293 & 3.32 & 0.73 & 2.82 & 0.73 & 3.43 & 2.88 & 2.53 & 3.13 & 2.70 \\
\hline$\left(\mathrm{O}_{\mathrm{Y}}^{-}, \mathrm{N}, \mathrm{HO}_{\mathrm{X}}^{+}\right)$ & -681.44922 & 2.99 & 1.01 & 2.92 & 1.02 & 2.93 & & & & \\
\hline $\begin{array}{l}\left(\mathrm{O}_{\mathrm{Y}}^{-}, \mathrm{HN}^{+}, \mathrm{O}_{\mathrm{X}}\right) \\
\text { (3) Anionic form }\end{array}$ & -681.45596 & 2.20 & 0.76 & 2.03 & 0.67 & 2.79 & & & & \\
\hline $\begin{array}{c}\left(\mathrm{O}_{\mathrm{Y}}^{-}, \mathrm{N}, \mathrm{O}_{\mathrm{X}}\right)^{-} \\
\text {(4) Cationic form }\end{array}$ & -680.95531 & 2.26 & 0.83 & 2.17 & 0.79 & 2.86 & - & 2.97 & 2.60 & 2.44 \\
\hline$\left(\mathrm{HO}_{\mathrm{Y}}, \mathrm{HN}^{+}, \mathrm{O}_{\mathrm{X}}\right)^{+}$ & -681.86081 & 2.71 & 0.70 & - & - & 3.41 & & & & \\
\hline$\left(\mathrm{O}_{\mathrm{Y}}^{-}, \mathrm{HN}^{+}, \mathrm{HO}_{\mathrm{X}}^{+}\right)^{+}$ & -681.82365 & 3.29 & 0.91 & - & - & 2.95 & & & & \\
\hline$\left(\mathrm{HO}_{\mathrm{Y}}, \mathrm{N}, \mathrm{HO}_{\mathrm{X}}^{+}\right)^{+}$ & -681.85748 & 2.41 & 1.24 & - & - & 3.05 & & & & \\
\hline (5) Dicationic form & & & & & & & & & & \\
\hline$\left(\mathrm{HO}_{\mathrm{Y}}, \mathrm{HN}^{+}, \mathrm{HO}_{\mathrm{X}}^{+}\right)^{2+}$ & -682.06908 & 2.45 & 0.81 & - & - & 3.00 & & & & \\
\hline
\end{tabular}

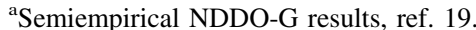

${ }^{\mathrm{b}}$ Multi-Configurational Quasi-Degenerate Perturbation Theory, ref. 29.

${ }^{\mathrm{c}}$ Ref. 13.

${ }^{\mathrm{d}}$ Ground-state energy calculated by the SAC method corrected by the solvation energy estimated by a continuum model (atomic units).

${ }^{\mathrm{e}}$ Excitation energy for the first excited state corrected by the solvation energy $(\mathrm{eV})$.

${ }^{\mathrm{f}}$ Oscillator strength for the excitation (atomic units).

${ }^{g}$ Fluorescence energy from the first excited state corrected by the solvation energy $(\mathrm{eV})$.

${ }^{\mathrm{h}}$ Oscillator strength for the emission (atomic units).

candidates, because the computed excitation energies are 2.26 and $2.20 \mathrm{eV}$, respectively. The computed Stokes shifts are 0.09 and $0.17 \mathrm{eV}$, respectively, which are comparable to the experimental value, $0.16 \mathrm{eV}$. Although the computed excitation and fluorescent energies for the anionic form are closer to the experimental values than those for the zwitterionic form, this is still not conclusive evidence. Considering the ground-state stability, it would be difficult to create the zwitterionic form, because it is about $17 \mathrm{kcal} / \mathrm{mol}$ less stable than the neutral form. In addition, the $\mathrm{p} K_{\mathrm{a}}$ of the $\mathrm{N}$ site is small enough that the position cannot be protonated by the acidic residues in the GFP protein. Therefore, the anionic form is much more likely to be the protonation state of the B-form. Recently, the results of a hole-burning spectroscopic study suggested that another state, I-form, contributes to the absorption spectrum of wild-type GFP as a broad wing to the red-side of the $475 \mathrm{~nm}$ peak (the B-form $).{ }^{14}$ The zwitterionic state $\left(\mathrm{O}_{\mathrm{Y}}^{-}, \mathrm{NH}^{+}, \mathrm{O}_{\mathrm{X}}\right)$ has an excitation energy of $2.20 \mathrm{eV}$, which is lower than that of the anionic form by $0.06 \mathrm{eV}$. This result supports a previous proposal based on a semiempirical MO calculations. ${ }^{19}$
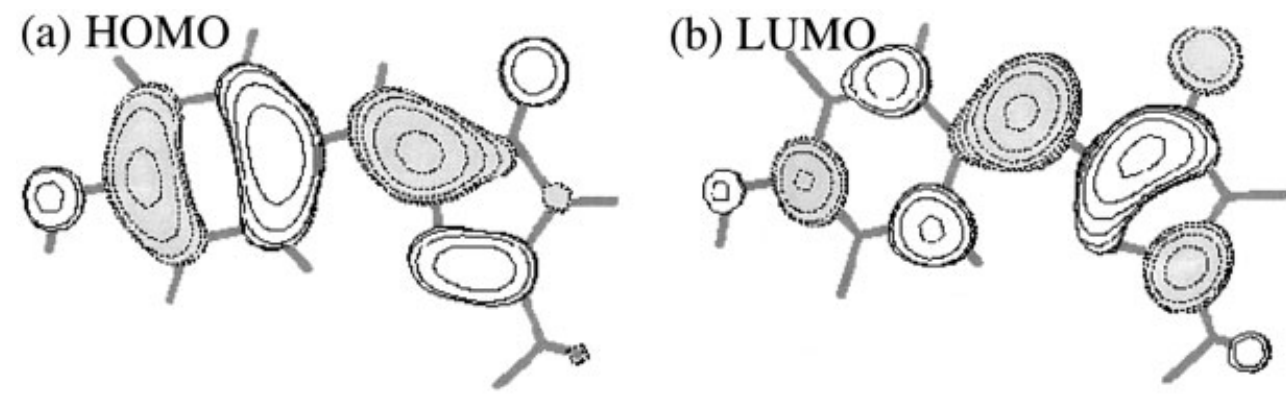

Figure 2. Highest occupied (HOMO) and lowest unoccupied (LUMO) molecular orbitals of the chromophore in the neutral protonation state $\left(\mathrm{HO}_{\mathrm{Y}}, \mathrm{N}, \mathrm{O}_{\mathrm{X}}\right)$, calculated by the Hartree-Fock method. 
Thus far, there is no evidence that the cationic and dicationic forms exist in intact wild-type GFP. According to a previous theoretical study, they can exist only under acidic conditions of $\mathrm{pH}$ below 1.1. ${ }^{28}$ The first excitation energies of the three cationic forms $\left[\left(\mathrm{HO}_{\mathrm{Y}}, \mathrm{HN}, \mathrm{O}_{\mathrm{X}}\right)^{+},\left(\mathrm{O}_{\mathrm{Y}}, \mathrm{HN}, \mathrm{HO}_{\mathrm{X}}\right)^{+},\left(\mathrm{HO}_{\mathrm{Y}}, \mathrm{N}, \mathrm{HO}_{\mathrm{X}}\right)^{+}\right]$ and a dicationic form $\left[\left(\mathrm{HO}_{\mathrm{Y}}, \mathrm{HN}, \mathrm{HO}_{\mathrm{X}}\right)^{2+}\right]$ are calculated to be $2.71,3.29,2.41$, and $2.45 \mathrm{eV}$, respectively, which are relatively close to the experimental values. However, the X-ray structure ${ }^{27,58}$ indicates that the protonation at the $\mathrm{N}$ and $\mathrm{O}_{\mathrm{x}}$ sites in the chromophore would be difficult, because there is no strongly acidic side-chain in their proximity.

\section{Conclusion}

The SAC/SAC-CI method was used to calculate the excitation energies and fluorescence energies of the GFPC in its various protonation states. The effects on the excitation energies and fluorescence energies due to the polarization effect of protein was also calculated using a continuum model. Based on the SAC-CI excitation energies, fluorescence energies, and the stability of the chromophore in its neutral, zwitterionic, and anionic forms, we assigned the A-form at around $398 \mathrm{~nm}(3.13 \mathrm{eV})$ to the neutral conformation $\left(\mathrm{HO}_{\mathrm{Y}}, \mathrm{N}, \mathrm{O}_{\mathrm{X}}\right)$ of the chromophore and the B-form at around $478 \mathrm{~nm}(2.60 \mathrm{eV})$ to the anionic form $\left(\mathrm{O}_{\mathrm{Y}}^{-}, \mathrm{N}, \mathrm{O}_{\mathrm{X}}\right)^{-}$of the chromophore. This assignment supports the previous experimental observations. . $^{13,17,19}$

\section{Acknowledgments}

This study was supported by a Grant-in-Aid for Creative Scientific Research from the Ministry of Education, Culture, Sports, Science, and Technology of Japan. A. K. D. is grateful to the Japan Society for the Promotion of Science (JSPS) for providing a fellowship to study at Kyoto University.

\section{References}

1. Shimomura, O.; Johnson, F. H.; Saiga, Y. J Cell Comp Physiol 1962, $59,223$.

2. Morin, J. G.; Hastings, J. W. J Cell Physiol 1971, 77, 313.

3. Morise, H.; Shimomura, O.; Johnson, F. H.; Winant, J. J Biochem 1974, 13, 2656

4. Ward, W. W. Photochem Photobiol Rev 1979, 4, 1.

5. Cubitt, A. B.; Heim, R.; Adams, S. R.; Boyd, A. E.; Gross, L. A.; Tsien, R. Y. Trends Biochem Sci 1995, 20, 448.

6. Prasher, D. C. Trends Genet 1995, 11, 320.

7. Tsien, R. Y. Annu Rev Biochem 1998, 67, 509.

8. Palm, G. T.; Wlodawer, A. Methods Enzymol 1999, 302, 378.

9. Inouye, S.; Tsuji, F. I. FEBS Lett 1994, 341, 277.

10. Johnson, F. H.; Shimomura, O.; Saiga, Y.; Gershman, L. C.; Reynolds, G. T.; Walter, J. R. J Cell Comp Physiol 1962, 60, 85.

11. Cody, C., W.; Prasher, D. C.; Westler, W. M.; Prendergast, F. G.; Ward, W. W. Biochemistry 1933, 32, 1212.

12. Prasher, D. C.; Eckrnrode, V. K.; Ward, W. W.; Prendergast, F. G.; Cormier, M. J. Gene 1992, 111, 229.
13. Chattoraj, M.; King, B. A.; Bublitz, G. U.; Boxer, S. G. Proc Natl Acad Sci USA 1996, 93, 8362.

14. Creemers, T. M. H.; Lock, A. J.; Subramaniam, V.; Jovin, T. M.; Volker, S. Nat Struct Biol 1999, 6, 558.

15. Ward, W. W.; Prentice, H. J.; Roth, A. F., Cody, C. W.; Reeves, S. C. Photochem Photobiol 1982, 35, 803.

16. Ward, W. W.; Cody, C. W.; Hart, R. C.; Cormier, M. J Photochem Photobiol 1980, 31, 611.

17. Bell, A. F.; He, X.; Wachter, R. M.; Tonge, P. J. Biochemistry 2000, $39,4423$.

18. He, X.; Bell, A. F.; Tonge, P. J. J Phys Chem B 2002, 106, 6056.

19. Voityuk, A. A.; Kummer, A. D.; Michel-Beyerle, M.-E.; Rosch, N. Chem Phys 2001, 269, 83.

20. Litvinenko, K. L.; Webber, N. M.; Meech, S. R. Chem Phys Lett 2001, $346,47$.

21. Webber, N. M.; Litvinenko, K. L.; Meech, S. R. J Phys Chem B 2001, $105,8036$.

22. Litvinenko, K. L.; Webber, N. M.; Meech, S. R. Bull Chem Soc Jpn 2002, 75, 1065

23. Nielsen, S. B.; Lapierre, A.; Andersen, J. U.; Pedersen, U. V.; Tomita, S.; Andersen, L. H. Phys Rev Lett 2001, 87, 228102.

24. Andersen, L. H.; Lapierre, A.; Nielsen, S. B.; Nielsen, I. B.; Pedersen, S. U.; Pedersen, U. V.; Tomita, S. Eur Phys J D 2002, 20, 597.

25. Yang, F.; Moss, L. G.; Phillips, G. N. Nat Biotech 1996, 14, 1246.

26. Brejc, K.; Sixma, T. K.; Kitts, P. A.; Kain, S. R.; Tsien, R. Y.; Ormoe, M.; Remington, S. J. Proc Natl Acad Sci USA 1997, 94, 2306.

27. Elsliger, M. A.; Wachter, R. M.; Hanson, G. T.; Kallio, K.; Remington, S. J. Biochemistry 1999, 38, 5296.

28. Yazal, J. E.; Prendergast, F. G.; Shaw, D. E.; Pang, Y.-P. J Am Chem Soc 2000, 122, 11411

29. Helms, V.; Winstead, C.; Langhoff, P. W. J Mol Struct (THEOCHEM) 2000, 506, 179.

30. Weber, W.; Helms, V.; McCammon, J. A.; Langhoff, P. W. Proc Natl Acad Sci USA 1999, 96, 6177.

31. Voityuk, A. A.; Michel-Beyerle, M.-E.; Rosch, N. Chem Phys Lett 1998, 296, 269.

32. Voityuk, A. A.; Michel-Beyerle, M.-E.; Rosch, N. Chem Phys 1998, $231,13$.

33. Nakatsuji, H.; Hirao, K. J Chem Phys 1978, 68, 2053.

34. Nakatsuji, H. Chem Phys Lett 1978, 59, 362.

35. Nakatsuji, H. Chem Phys Lett 1979, 67, 329.

36. Nakatsuji, H. Chem Phys Lett 1979, 67, 334.

37. Nakatsuji, H. Acta Chim Hungarica, Models in Chemistry 1992, 129, 719.

38. Nakatsuji, H. In Computational Chemistry - Reviews of Current Trends, Vol. 2; Leszczynski, J., Ed.; World Scientific: Singapore, 1997; pp 62-124.

39. Karelson, M. K.; Zerner, M. C. J Phys Chem 1992, 96, 6949.

40. Onsanger, L. J Am Chem Soc 1936, 58, 1486.

41. Nakatsuji, H.; Hirao, K.; Mizukami, Y. Chem Phys Lett 1991, 179, 555.

42. Hasegawa, J.; Ohkawa, K.; Nakatsuji, H. J Phys Chem B 1998, 102, 10410.

43. Kurimoto, M.; Subramony, P.; Gurney, R. W.; Lovell, S.; Chimielewski, J.; Kahr, B. J Am Chem Soc 1999, 121, 6952.

44. Hohenberg, P.; Kohn, W. Phys Rev 1964, 136, B864.

45. Kohn, W.; Sham, L. J Phys Rev 1965, 140, A1133.

46. Parr, R. G.; Yang, W. Density-Functional Theory of Atoms and Molecules; Oxford University Press: Oxford, 1989.

47. Lee, C.; Yang, W.; Parr, R. G. Phys Rev B 1988, 37, 785.

48. Becke, A. D. J Chem Phys 1993, 98, 5648.

49. Hehre, W. J.; Ditchfield, R.; Pople, J. A. J Chem Phys 1972, 56, 2257.

50. Hariharan, P. C.; Pople, J. A. Theor Chim Acta 1973, 28, 213. 
51. Huzinaga, S.; Andzelm, J.; Klobukowski, M.; Radzio-Andzelm, E.; Sakai, Y.; Tatewaki, H. Gaussian Basis Set for Molecular Calculations; Elsevier: New York, 1984.

52. Handbook of Chemistry and Physics, 65th edition; C. R. C. Press Inc.: Boca Raton, FL, 1984-1985.

53. Frisch, M. J.; Trucks, G. W.; Schlegel, H. B.; Scuseria, G. E.; Robb, M. A.; Cheeseman, J. R.; Montgomery, J.; Vreven, T.; Kudin, K. N.; Burant, J. C.; Millam, J. M.; Iyengar, S. S.; Tomasi, J.; Barone, V.; Mennucci, B.; Cossi, M.; Scalmani, G.; Rega, N.; Petersson, G. A.; Nakatsuji, H.; Hada, M.; Ehara, M.; Toyota, K.; Fukuda, R.; Hasegawa, J.; Ishida, M.; Nakajima, T.; Honda, Y.; Kitao, O.; Nakai, H.; Klene, M.; Li, X.; Knox, J. E.; Hratchian, H. P.; Cross, J. B.; Adamo, C.; Jaramillo, J.; Gomperts, R.; Stratmann, R. E.; Yazyev, O.; Cammi, R.; Pomelli, C.; Ochterski, J.; Ayala, P. Y.; Morokuma, K.; Hase, W. L.; Voth, G.; Salvador, P.; Dannenberg, J. J.; Zakrzewski, V. G.; Dapprich, S.; Daniels, A. D.; Strain, M. C.; Farkas, O.; Malick, D. K.; Rabuck, A. D.; Raghavachari, K.; Foresman, J. B.; Ortiz, J. V.; Cui, Q.; Baboul, A. G.; Clifford, S.; Cioslowski, J.; Stefanov, B. B.; Liu, G.; Liashenko, A.; Piskorz, P.; Komaromi, I.; Martin, R. L.; Fox, D. J.; Keith, T.; Al-Laham, M. A.; Peng, C. Y.; Nanayakkara, A.; Challacombe, M.; Gill, P. M. W.; Johnson, B.; Chen, W.; Wong, M. W.; Gonzalez, C.; Pople, J. A. Gaussian Development Version, Revision A.03; Gaussian, Inc.: Pittsburgh, PA, 2003.
54. Nakatsuji, H. Chem Phys 1983, 75, 425.

55. Frisch, M. J.; Trucks, G. W.; Schlegel, H. B.; Scuseria, G. E.; Robb, M. A.; Cheeseman, J. R.; Zakrzewski, V. G.; Montgomery, J.; Stratmann, R. E.; Burant, J. C.; Dapprich, S.; Millam, J. M.; Daniels, A. D.; Kudin, K. N.; Strain, M. C.; Farkas, O.; Tomasi, J.; Barone, V.; Cossi, M.; Cammi, R.; Mennucci, B.; Pomelli, C.; Adamo, C.; Clifford, S.; Ochterski, J.; Petersson, G. A.; Ayala, P. Y.; Cui, Q.; Morokuma, K.; Rega, N.; Salvador, P.; Dannenberg, J. J.; Malick, D. K.; Rabuck, A. D.; Raghavachari, K.; Foresman, J. B.; Cioslowski, J.; Ortiz, J. V.; Baboul, A. G.; Stefanov, B. B.; Liu, G.; Liashenko, A.; Piskorz, P.; Komaromi, I.; Gomperts, R.; Martin, R. L.; Fox, D. J.; Keith, T.; Al-Laham, M. A.; Peng, C. Y.; Nanayakkara, A.; Challacombe, M.; Gill, P. M. W.; Johnson, B.; Chen, W.; Wong, M. W.; Andres, J. L.; Gonzalez, C.; Head-Gordon, M.; Replogle, E. S.; Pople, J. A. Gaussian 98 Revision A.11.3; Gaussian, Inc.: Pittsburgh, PA, 2002.

56. Niwa, H.; Inouye, S.; Hirano, T.; Matsuno, T.; Kojima, S.; Kubota, M.; Ohashi, M.; Tsuji, F. I. Proc Natl Acad Sci USA 1996, 93, 13617

57. Bublitz, G. U.; King, B. A.; Boxer, S. G. J Am Chem Soc 1998, 120, 9370.

58. Wachter, R. M.; King, B. A.; Heim, R.; Kallio, K.; Tsien, R. Y.; Boxer, S. G.; Remington, S. J. Biochemistry 1997, 36, 9759. 